\title{
PENGARUH MEDIA PEMBELAJARAN DAN KEMAMPUAN SIGHT SINGING TERHADAP HASIL BELAJAR MUSIK ANSAMBEL
}

\author{
Asima Sidabutar \\ Guru SMP Swasta Bodhicitta Medan, Sumatera Utara \\ asima.sidabutar@gmail.com
}

\begin{abstract}
Abstrak: Penelitian ini bertujuan untuk mengetahui: (1) perbedaan hasil belajar musik ansambel siswa yang diajarkan dengan menggunakan media power point dengan siswa yang diajarkan dengan menggunakan media video; (2) perbedaan hasil belajar siswa yang memiliki kemampuan sight singing tinggi dengan siswa yang memiliki keampuan sight singing rendah; dan (3) interaksi antara media power point dengan kemampuan sight singing dalam mempengaruhi hasil belajar musik ansambel siswa. Metode penelitian menggunakan penelitian eksperimen semu (quasi experiment). Analisis data yang digunakan adalah ANAVA Faktorial $2 \times 2$. Berdasarkan hasil penelitian diperoleh: (1) terdapat perbedaan hasil belajar musik ansambel antara siswa kelas media pembelajaran power point dengan hasil belajar musik ansambel siswa kelas media pembelajaran video; (2) terdapat perbedaan hasil belajar musik ansambel antara siswa yang memiliki kemampuan sight singing tinggi dengan siswa yang memiliki kemampuan sight singing rendah; dan (3) ada interaksi antara media pembelajaran dan kemampuan sight singing terhadap hasil belajar musik ansambel. Dengan demikian disarankan guru harus lebih cermat dalam memilih dan menggunakan media pembelajaran yang sesuai dengan tujuan pembelajaran yang akan dicapai. Media power point merupakan media yang dapat digunakan dalam pembelajaran musik ansambel, dimana hasil penelitian ini menunjukkan bahwa media pembelajaran power point memberikan pengaruh yang lebih baik terhadap hasil belajar.
\end{abstract}

Kata Kunci: media pembelajaran, sight singing, musik ansambel.

Abstract: The aims of this study were to determine: (1) difference in student's ensemble music learning outcomes taught by using power point media and video media. (2) difference in learning outcomes of students who have a high ability to sight singing with student who have a low level of ability sight singing, and (3) the interaction between media power point with sight singing abilities in influencing student learning outcomes music ensemble. The research method used is quasiexperimental research (quasi experiment). Analysis of data used is $2 \times 2$ factorial ANOVA. result showed: (1) there is a difference in learning outcomes between music ensemble students using instructional media power point with the music ensemble of students using media video; (2) there are differences in learning outcomes between students studying music ensemble that has a high ability to sight singing with students who have lower sight singing ability; (3) there is an interaction between the learning media and sight singing abilities on learning outcomes ensemble music. It isi suggested that, teachers should be more careful in selecting and using learning media in accordance with the objectives to be achieved. Power point is a media that can be used in teaching music ensemble, where the results of this study indicate that the learning media with power point gives a better effect on learning outcomes.

Keywords: learning media, sight singing, ensemble music.

\section{PENDAHULUAN}

Pendidikan merupakan hal yang sangat penting bagi suatu negara. Pemerintah memiliki peran dalam meningkatkan mutu pendidikan. Peran pemerintah adalah meningkatkan sistem pendidikan dengan melakukan perbaikan-perbaikan untuk dapat meningkatkan standar pendidikan. Namun hal itu bukanlah hal yang mudah, bukan seperti membalikkan telapak tangan. Melihat kondisi pendidikan Indonesia saat ini menuntut pemerintah yakni Kementerian Pendidikan dan Kebudayaan untuk bekerja lebih keras untuk memperbaiki sistem dalam pendidikan yang saat ini cukup memprihatinkan. 
Indonesia termasuk dalam 10 negara dengan kinerja kategori rendah. Trends in International Mathematics and Science Studies tahun 2011, Indonesia berada pada posisi 40 dari 42 negara untuk literasi sains. TIMSS \& PIRLS pada tahun 2011 menyebutkan bahwa kinerja Indonesia pada Mathematics berada diurutan ke-38 dari 42 negara, pada bidang Science berada pada urutan ke-40 dari 42 negara, dan bidang Reading pada urutan ke-41 dari 45 (Baswedan, 2014).

Kondisi pendidikan Indonesia saat ini memerlukan perhatian khusus. Salah satu hal yang juga menjadi masalah adalah kurangnya pemerataan baik dari segi penyediaan fasilitas sekolah maupun pembangunan infrastruktur sekolah. Banyak sekolah yang tidak memiliki fasilitas dan juga media pembelajaran. Hal ini sering terjadi pada sekolah-sekolah di daerah terpencil. Hal ini sangat ironis jika dibandingkan dengan sekolah-sekolah di kota besar justru memiliki fasilitas dan media pembelajaran yang sangat lengkap.

Menurut Hamalik (2009:36) belajar adalah modifikasi atau memperteguh kelakuan melalui pengalaman. Menurut pengertian ini belajar merupakan suatu proses atau suatu kegiatan dan bukan suatu hasil atau tujuan. Belajar tidak hanya mengingat tapi juga mengalami. Hasil belajar bukan suatu penguasaan hasil latihan, melainkan perubahan tingkah laku. Belajar dipahami sebagai suatu perilaku.

Menurut Hilgard dalam Hamdani (2010:21) belajar adalah proses timbulnya suatu perilaku dan berubahnya suatu perilaku karena adanya respon terhadap suatu situasi. Belajar terjadi apabila suatu situasi stimulus dengan isi memengaruhi siswa sedemikian rupa sehingga perbuatannya berubah dari waktu sebelum ia mengalami sesuatu itu ke waktu setelah ia mengalami situasi tersebut. Gagne berpendapat ada tiga tahap dalam belajar yaitu:(1) Persiapan untuk belajar dengan melakukan tindakan mengarahkan perhatian, pengharapan dan mendapatkan kembali informasi. (2) Pemerolehan dan unjuk perbuatan digunakan untuk persepsi selektif, sandi semantic, pembangkitan kembali, respons, dan penguatan. (3) Alih belajar yaitu pengisyaratan untuk membangkitkan dan memberlakukan secara umum.

Sudjana (2010:3) mendefinisikan hasil

belajar siswa pada hakikatnya adalah perubahan tingkah laku sebagai hasil belajar dalam pengertian yang lebih luas mencakup bidang kognitif, afektif, dan psikomotorik. Hasil belajar merupakan hasil dari suatu interaksi tindak belajar dan tindak mengajar. Dari sisi guru, tindak mengajar diakhiri dengan proses evaluasi hasil belajar. Dari sisi siswa, hasil belajar merupakan berakhirnya pengajaran dari puncak proses belajar. Menurut Hamdani (2010:4) untuk mencapai hasil pembelajaran harus diperhatikan kondisi pembelajaran yang meliputi karakteristik siswa serta pemilihan strategi yang disesuaikan dengan materi dan kondisi siswa. Siswa dikatakan berhasil dalam proses pembelajaran jika siswa tersebut telah dapat berperilaku sesuai dengan kompetensi-kompetensi yang diharapkan dari pembelajaran sejarah baik dari aspek kognitif, efektif, maupun psikomotorik. Untuk mengetahui apakah siswa telah menguasai sejumlah kompetensi sebagian hasil dari belajar, perlu dilakukan evaluasi. Evaluasi digunakan sebagai alat kontrol untuk mengetahui sejauh mana seseorang telah mencapai hasil belajar.

Salah satu materi pelajaran seni musik adalah musik ansambel. Musik ansambel merupakan kegiatan bermain musik secara bersama-sama. Berdasarkan hasil penelitian awal yang dilakukan oleh peneliti membuktikan bahwa, para guru seni musik umumnya tidak menggunakan media apapun dalam pembelajarannya. Dalam pembelajaran musik ansambel pada umumnya, guru mendemonstrasikan permainan musik secara langsung di hadapan para siswa. Hal ini sangat menyulitkan guru, sebab dalam musik ansambel terdapat beberapa jenis alat musik yang digunakan sehingga waktu pembelajaran menjadi tidak efektif.

Pembelajaran seni musik di sekolah bergerak pada bidang teori dan praktek. Pembelajaran musik ansambel termasuk ke dalam pembelajaran bidang praktek. Menurut Tambajong dalam Ensiklopedia musik (1992 :130), Ansambel atau Ensemble diartikan sebagai kelompok orang-orang yang bernyanyi, dengan atau tanpa iringan instrumen, atau dapat juga sekelompok pemain musik, dengan atau tanpa penyanyi.

Menurut

Banoe

(2003:133)

menyatakan bahwa Ansambel atau Ensemble adalah kelompok musik dalam satuan kecil, atau permainan bersama dalam satuan kecil alat musik. Selain itu, Banoe mengartikan ansambel sebagai kesatuan, kebersamaan, satuan musik 
yang bermain bersama-sama dengan tidak mempedulikan jumlah sedikit maupun jumlah banyak pemain. Istilah ansambel disesuaikan dengan alat musik yang terdapat di dalamnya. Misalnya Wind Instrumen Ensemble (Ansambel Musik Tiup) maka alat musik yang ada di dalamnya adalah alat-alat musik yang dimainkan dengan cara ditiup seperti piccolo, flute, oboe, clarinet, saxophone dan lainnya. Percussion Music Ensemble (Ansambel Musik Perkusi) maka alat musik yang dimainkan di dalamnya adalah alat musik yang dimainkan dengan cara dipukul seperti drum, timpani, tamborin, triangel, dan sebagainya.

Dalam permainan musik ansambel, pengetahuan tentang teori dasar musik memegang peranan penting. Menurut Eric (1989:7) unsur-unsur penting yang terdapat dalam musik ansambel adalah: (1) Melodi, menurut Banoe (2003:270) melodi adalah lagu pokok. Menurut Mack (1995:9) melodi merupakan unsur hakikat musik yang sesungguhnya, karena merupakan isi pokok dalam sebuah karya musik. Dalam musik ansambel, melodi dituliskan ke dalam bentuk notasi musik baik notasi angka, maupun notasi balok.

Menurut Sudjana (2010:4) untuk mencapai hasil pembelajaran harus diperhatikan kondisi pembelajaran yang meliputi karakteristik siswa serta pemilihan strategi yang disesuaikan dengan materi dan kondisi siswa. Siswa dikatakan berhasil dalam proses pembelajaran jika siswa tersebut telah dapat berperilaku sesuai dengan kompetensikompetensi yang diharapkan dari pembelajaran sejarah baik dari aspek kognitif, efektif, maupun psikomotorik. Untuk mengetahui apakah siswa telah menguasai sejumlah kompetensi sebagian hasil dari belajar, perlu dilakukan evaluasi. Evaluasi digunakan sebagai alat kontrol untuk mengetahui sejauh mana seseorang telah mencapai hasil belajar.

Kata media berasal dari bahasa Latin yaitu medius yang secara harafiah berarti tengah, perantara, atau pengantar. Gerlach \& Ely (1971:166) menyatakan bahwa media apabila dipahami secara garis besar adalah manusia, materi atau kejadian yang membangun kondisi yang membuat siswa mampu memperoleh pengetahuan, keterampilan, atau sikap. Secara lebih khusus pengertian media dalam proses belajar mengajar cenderung diartikan sebagai alat-alat grafis, photografis, atau elektronis untuk menangkap, memproses, dan menyusun kembali informasi visual atau verbal.

AECT (Association of education and Communication Technology) dalam Arsyad (2013:3) memberi batasan tentang media sebagai segala bentuk dan saluran yang digunakan untuk meyampaikan pesan atau informasi. Di samping sebagai sistem penyampai atau pengantar, media yang sering diganti dengan kata mediator. Menurut Fleming dalam Arsyad (2013:3) mediator adalah penyebab atau alat yang turut campur tangan dalam dua pihak dan mendamaikannya. Dengan istilah mediator, media menunjukkan fungsi atau perannya yaitu mengatur hubungan yang efektif antara dua pihak utama dalam proses belajar yakni siswa dan isi pelajaran. Di samping itu, mediator dapat pula mencerminkan pengertian bahwa setiap system pembelajaran yang melakukan peran mediasi, mulai dari guru sampai kepada peralatan paling canggih, dapat disebut media. Maka dapat disimpulkan bahwa media adalah alat yang berfungsi untuk menyampaikan atau mengantarkan pesan-pesan kepada penerima pesan. Apabila media itu membawa pesanpesan atau informasi yang bertujuan instruksional atau mengandung maksudmaksud pengajaran maka media itu disebut media pembelajaran.

Menurut Gagne and Briggs (1979:178) media pembelajaran meliputi alat yang secara fisik digunakan untuk menyampaikan isi materi pelajaran, yang terdiri dari antara lain buku, tape recorder, kaset, video kamera, video recorder, film, slide (gambar bingkai), foto, gambar, grafik, televisi, dan komputer.

Menurut Hamdani (2010: 244) media pembelajaran dalam proses belajar mengajar dapat membangkitkan keinginan dan minat yang baru, membangkitkan motivasi dan rangsangan kegiatan belajar bahkan membawa pengaruh-pengaruh psikologis terhadap siswa. Sanjaya (2008:47) menyatakan bahwa media pembelajaran meliputi perangkat keras yang dapat mengantarkan pesan dan perangkat lunak yang mengandung pesan. Media tidak hanya berupa alat atau bahan, tetapi juga hal-hal lain yang memungkin siswa memperoleh pengetahuan. Berdasarkan pendapat-pendapat tersebut di atas maka dapat disimpulkan bahwa media pembelajaran adalah segala sesuatu yang dapat menyalurkan pesan, merangsang pikiran, perasaan dan kemauan siswa sehingga 
mendorong terciptanya proses belajar pada diri siswa.

Media video termasuk ke dalam jenis media audio visual atau disebut juga media pandang-dengar, dimana media ini akan menjadikan penyajian bahan ajar semakin lengkap dan optimal. Dalam batas-batas tertentu media ini dapat menggantikan tugas dan peran guru. Sebab penyajian materi bisa diganti oleh media, dan guru bisa beralih menjadi fasilitator belajar yaitu memberikan kemudahan bagi para siswa untuk belajar. Media video digunakan dengan menampilkan rekaman video berupa permainan ansambel tentang materi yang sedang dibahas di kelas. Media video menampilkan gambar dan suara sehingga siswa dalam masing-masing kelompok dapat melihat langsung penampilan musik ansambel, tanpa harus menunggu guru untuk menampilkannya di depan kelas.

Media video termasuk dalam jenis media audio visual. Menurut Arsyad (2013:249) media audio visual disebut juga media pandang-dengar, dimana media ini akan menjadikan penyajian bahan ajar semakin lengkap dan optimal. Dalam batas-batas tertentu media ini dapat menggantikan tugas dan peran guru. Sebab penyajian materi bisa diganti oleh media, dan guru bisa beralih menjadi fasilitator belajar yaitu memberikan kemudahan bagi para siswa untuk belajar. Selain video, media yang termasuk dalam jenis audio visual adalah televisi dan slide suara (soundslide).

Menurut Lavie \& Lavie dalam Arsyad (2013:251) menyimpulkan bahwa stimulus visual membuahkan hasil belajar yang lebih baik untuk tugas-tugas seperti mengingat, mengenali, mengingat kembali, dan menghubungkan fakta dan konsep. Belajar dengan menggunakn media pandang-dengar akan sangat bermanfaat bagi siswa. Siswa akan belajar lebih banyak daripada jika materi pelajaran disajikan hanya dengan stimulus pandang (penglihatan) atau hanya stimulus dengar (pendengaran) saja. Menurut Arsyad (2013: 13) perbandingan pemerolehan hasil belajar melalui indera pandang dan indera dengar sangat menonjol perbedaannya. Berdasarkan penelitian Baugh dalam Arsyad (2013: 13) bahwa kurang lebih 90\% hasil belajar seseorang diperoleh dari indera penglihatan, hanya sekitar $5 \%$ berasal dari indera pendengaran dan 5\% lagi berasal dari indera yang lain. Selain itu Dale dalam Arsyad
(2013: 13) juga memperkirakan bahwa pemerolehan hasil belajar melalui indera penglihatan berkisar 75\%, melalui indera pendengaran sekitar $13 \%$ dan sisanya $12 \%$ berasal dari indera lain.

Sanaky dalam Ginting (2015:32) menyatakan bahwa microsoft Power Point adalah program aplikasi presentasi yang merupakan salah satu program aplikasi di bawah microsoft office program komputer dan tampilan ke layar dengan menggunakan LCD projector. Keuntungan terbesar dalam program ini adalah tidak perlu pembelian piranti lunak karena sudah berada dalam microsoft office. Maka saat akan menggunakan aplikasi Power Point, sudah terinstal di dalam komputer. Dengan bantuan media Power Point guru dapat mempresentasikan materi ajar kepada siswa dengan lebih mudah menstranformasikan ilmunya melalui presentasi yang diberikan oleh guru kepada siswa. Disamping memudahkan guru dalam menguasai kelas, juga membantu siswa untuk tetap fokus pada materi yang disampaikan melalui media Power Point. Power Point adalah suatu software yang akan membantu dalam menyusun sebuah presentasi yang efektif, professional, dan juga mudah. Media Power Point bisa membantu sebuah gagasan menjadi lebih menarik dan jelas tujuannya. Power Point membantu dalam pembuatan slide, outline, presentasi, presentasi elektronika, slide yang dinamis, clipart yang menarik dan semuanya dapat ditampilkan di layar komputer.

Menurut Hamdani (2010: 254) power point sangat cocok untuk mengajarkan materi dalam ranah perilaku dan psikomotor. Selain itu memaparkan keadaan real dari suatu proses, fenomena atau kejadian sehingga dapat memperkaya pemaparan.

Penggunaan media Power Point dan media video dalam pembelajaran musik ansambel cukup menguntungkan guru, sebab waktu pembelajaran dapat dialokasikan dengan baik. Selain itu, jika siswa masih kurang mengerti, media Power Point dan media video dapat diulang kembali. Dalam arti, penggunaan media ini cukup praktis dan efisien.

Kemampuan Sight Singing merupakan bagian dari musik. Maka sebelum menjabarkan tentang kemampuan Sight Singing, maka perlu dijabarkan dahulu tentang musik. Istilah musik berasal dari bahasa Yunani yaitu mousike yang diterjemahkan ke dalam bahasa Latin yakni musica. Menurut ensiklopedia musik (1992: 
254) menjelaskan bahwa musik adalah nada atau suara dalam urutan nada yang disusun sedemikian rupa hingga mengandung keharmonisan, selain itu musik adalah serangkaian nada-nada yang memiliki keharmonisan dan makna serta memiliki bunyibunyi yang berirama.

Holmes dalam Sinaga (2010:17) menjelaskan lebih lanjut mengenai kemampuan sight singing berkaitan dengan kemampuan individu yaitu: (1) Analysis of eye movement berkaitan dengan kemampuan individu untuk melakukan gerakan mata dalam membaca notasi musik Holmes dalam Sinaga(2010:17) mengutip kajian yang berkaitan dengan analysis of eye movement yaitu penelitian yang dilakukan oleh Goolsby. Dalam hal ini Gollsby melakukan pengujian pengukuran terhadap analysis of eye movement dimana hasil temuannya menunjukkan terdapat hubungan analysis of eye movement dengan kemampuan sight singing. Semakin cepat dan baik gerakan mata dalam melihat notasi musik maka kemampuan sigh singing semakin baik. Untuk menguji dan mengukur kemampuan ini dilakukan dengan cara membaca notasi musik baik notasi angka maupun notasi balok, kemudian mengukur kecepatan dan ketepatannya membaca notasi musik tersebut. Berikut contoh notasi angka yang dapat digunakan untuk mengukur kemampuan analysis of eye movement.

Berdasarkan pengamatan dan pengalaman dari beberapa guru bidang studi seni musik di kota Medan, banyak para guru seni musik yang kesulitan dalam mempergunakan waktu pelajaran dengan maksimal. Jam pelajaran musik yang terbatas hanya sekitar 40 menit, cukup menyulitkan guru untuk membagi waktu dengan baik. Hal ini juga tentu berpengaruh pada siswa dan akhirnya akan berpengaruh pada hasil belajar siswa.

Rumusan masalah pada penelitian ini adalah: (1) Apakah pengaruh media Power Point terhadap peningkatan hasil belajar musik ansambel ?, (2) Bagaimana penerapan media Power Point dalam pembelajaran musik ansambel ?, (3) Apakah siswa yang memiliki kemampuan sight singing tinggi akan memiliki hasil belajar musik ansambel yang tinggi? Adapun hipotesis sebagai berikut ini, yaitu: (1) Hasil belajar musik Ansambel siswa yang diajarkan dengan media Power Point lebih tinggi daripada siswa yang diajar dengan media video, (2) Hasil belajar musik Ansambel siswa yang memiliki kemampuan sight singing tinggi lebih tinggi daripada siswa yang memiliki kemampuan sight singing yang rendah, (3) Terdapat interaksi antara media pembelajaran dengan kemampuan sight singing terhadap hasil belajar musik Ansambel.

\section{METODE}

Tempat penelitian dilaksanakan di SMP Swasta Perguruan Buddhis Bodhicitta Medan. Sekolah ini berada di jalan Selam No. 39 - 41 Medan. Penelitian ini dilaksanakan pada semester genap.

Penarikan sampel dilakukan secara acak melalui undi yakni dari 3 (tiga) kelas diperoleh 2 (dua) kelas eksperimen. Teknik pengambilan sampel dilakukan dengan teknik cluster random sampling, masing-masing kelas kemudian dikelompokan lagi untuk mengambil sampel dengan membagi 2 kelompok kemampuan sight singing tinggi dan kemampuan sight singing rendah, dari dua kelas yang telah terpilih sebagai sampel penelitian, selanjutnya melalui pengundian maka kelas VIII-1 terpilih sebagai kelas yang akan diajar dengan media Power Point sedangkan kelas VIII-3 terpilih sebagai kelas yang akan diajarkan dengan media video. Sebelum diberi perlakukan, kedua kelas sampel terlebih dahulu dilakukan tes untuk mengetahui tingkat kemampuan sight singing siswa. Dalam penelitian ini kemampuan sight singing dikategorikan atas kemampuan sight singing tinggi dan kemampuan sight singing rendah.

Penelitian ini menggunakan desain faktorial $2 \times 2$ sebagai variabel bebas pertama adalah penggunaan media pembelajaran yang dibedakan atas media Power Point dan media Video. Variabel moderator yaitu kemampuan sight singing siswa dengan pengelompokkan kemampuan sight singing tinggi dan kemampuan sight singing rendah. Sedangkan variabel terikatnya adalah hasil belajar musik ansambel. Desain penelitian ini dapat dilihat pada Tabel 2 berikut:

Tabel 2. Desain Faktorial 2 x 2

\begin{tabular}{|c|c|c|}
\hline $\begin{array}{l}\text { Media } \\
\text { Kemampuam } \\
\text { Sight singing }\end{array}$ & $\begin{array}{c}\text { Media } \\
\text { Power } \\
\text { Point }\end{array}$ & $\begin{array}{l}\text { Media } \\
\text { Video }\end{array}$ \\
\hline Tinggi $\left(\mathrm{B}_{1}\right)$ & $\mathrm{A}_{1} \mathrm{~B}_{1}$ & $\mathrm{~A}_{2} \mathrm{~B}_{1}$ \\
\hline Rendah $\left(\mathrm{B}_{2}\right)$ & $\mathrm{A}_{1} \mathrm{~B}_{2}$ & $\mathrm{~A}_{2} \mathrm{~B}_{2}$ \\
\hline
\end{tabular}


$\mathrm{A}_{1} \mathrm{~B}_{1}=$ Hasil belajar musik ansambel siswa yang dibelajarkan dengan menggunaakan media Power Point pada siswa dengan kemampuan sight singing tinggi.

$\mathrm{A}_{1} \mathrm{~B}_{2}=$ Hasil belajar musik ansambel siswa yang dibelajarkan dengan menggunaakan media Power Point pada siswa dengan kemampuan sight singing rendah.

$\mathrm{A}_{2} \mathrm{~B}_{1}=$ Hasil belajar siswa yang dibelajarkan dengan menggunakan media Video pada siswa dengan kemampuan sight singing tinggi.

$\mathrm{A}_{2} \mathrm{~B}_{2}=$ Hasil belajar siswa yang dibelajarkan dengan menggunakan media Video pada siswa dengan kemampuan sight singing rendah.

Rancangan desain faktorial 2 × 2 digunakan untuk memperkecil kesalahan dalam perbedaan hasil belajar musik ansambel yang disebabkan oleh tingkat kemampuan sight singing siswa. Lembar observasi yang diberikan kepada expert atau tim ahli yang dapat menilai, akan digunakan untuk mengklasifikasikan siswa atas kemampuan sight singing tinggi dan kemampuan sight singing rendah.

Instrumen pengumpulan data yang dilakukan dalam penelitian ini adalah lembar observasi yang digunakan selama melakukan pengamatan, yang terdiri dari instrumen test kemampuan sight singing untuk mengetahui kemampuan awal sight singing siswa, dan instrumen test hasil belajar musik ansambel.

Instrumen yang digunakan untuk mengukur hasil belajar musik ansambel dan kemampuan sight singing adalah berbentuk tes praktek. Tes ini meliputi empat klasifikasi dalam ranah psikomotorik berdasarkan teori Simpson dalam Panjaitan (2010:8) kawasan psikomotor meliputi enam kawasan perilaku yaitu: (1) Persepsi, (2) Kesiapan, (3) Gerakan terbimbing, (4) Gerakan terbiasa, (5) Gerakan yang kompleks, dan (6) Penyesuaian dan keaslian.

Teknik pengumpulan data dalam penelitian ini yaitu dengan menggunakan pengamatan atau observasi. Hal ini didasarkan pada pendapat Panjaitan (2010:32) menyatakan bahwa untuk mengevaluasi hasil belajar domain psikomotor harus dilakukan melalui pengamatan (observasi) terhadap siswa. Dalam melakukan observasi ini pengamat selain melakukan evaluasi terhadap perilaku yang ditampilkan siswa, tetapi sekaligus pengamat dapat belajar dari hasil pengamatan terhadap perilaku yang ditampilkan siswa yang dalam hal ini sebagai model. Pengamatan dilakukan dengan berpedoman pada lembar observasi dan melakukan pencatatan terhadap proses pembelajaran musik ansambel, serta melakukan tes untuk mengetahui kemampuan awal siswa sebelum diberikaan perlakuan dan tes akhir setelah perlakuan diberikan.

Uji coba terhadap instrumen dilakukan agar instrumen yang digunakan dalam penelitian valid dan reliabel. Item yang valid dan reliabel ini yang selanjutnya digunakan sebagai instrumen yang diujikan pada kelas perlakuan. menurut Sugiyono (2008:172) Sebuah tes dikatakan valid apabila tes tersebut dapat mengukur apa yang akan hendak diukur. Instrumen yang digunakan dalam penelitian harus mampu mengukur apa yang seharusnya diukur (validitas) dan seberapa jauh suatu alat pengukur tersebut andal (reliable) dan dapat dipercaya.

Teknik analisis data dalam penelitian ini menggunakan analisis deskriptif dan analisis inferensial. Teknik analisis deskriptif dimaksudkan untuk mendeskripsikan data penelitian meliputi mean, median, standar deviasi dan kecenderungan data. Untuk menguji kebenaran hipotesis yang diajukan dalam penelitian ini, maka teknik analisis data yang digunakan adalah analisis varians (ANAVA). Penggunaan teknik ini dengan maksud agar hasil tes akhir yang dicapai oleh subjek penelitian benar - benar akibat pengaruh dari perlakuan yang diberikan selama penelitian. Taraf signifikan yang digunakan dalam penelitian ini adalah ${ }^{\propto}=0,05$. Karena hasil pengujian menunjukan terdapatnya interaksi maka perlu dilakukan uji lanjut dengan uji Scheffe karena $\mathrm{n}$ tiap sel berbeda. Namun bila sama, maka dilanjutkan dengan uji Tuckey.

\section{HASIL PENELITIAN}

Pengujian Hipotesis penelitian pertama, kedua dan ketiga dilakukan dengan menggunakan analisis varians faktorial $2 \times 2$, perhitungan selengkapnya dapat dilihat pada lampiran 18. Rangkuman hasil perhitungannya pada tabel 3 sebagai berikut : 
Tabel 2. Rangkuman Tabel Anava Sight Singing dengan Media Pembelajaran.

\begin{tabular}{|c|c|c|c|c|}
\hline \multirow{2}{*}{ Sight singing } & \multirow{2}{*}{ Statistik } & \multicolumn{2}{|c|}{ Media Pembelajaran } & \multirow{2}{*}{ Total } \\
\hline & & Power point & Video & \\
\hline \multirow{4}{*}{ Tinggi } & $\mathrm{N}$ & 19 & 20 & 39 \\
\hline & $\Sigma \mathrm{X}$ & 1320 & 1392.5 & 2712.5 \\
\hline & $\Sigma \mathrm{X}^{2}$ & 93725 & 97643.75 & 191368.75 \\
\hline & $\mathrm{M}$ & 69.47 & 69.63 & 139.10 \\
\hline \multirow{4}{*}{ Rendah } & $\mathrm{N}$ & 21 & 21 & 42 \\
\hline & $\Sigma X$ & 1387.5 & 882.5 & 2270 \\
\hline & $\Sigma X^{2}$ & 95531.25 & 36975 & 132506.25 \\
\hline & M & 66.07 & 42.02 & 108.10 \\
\hline \multirow{4}{*}{ Total } & $\mathrm{N}$ & 40 & 41 & 81 \\
\hline & $\Sigma \mathrm{X}$ & 2707.5 & 2275 & 4982.5 \\
\hline & $\Sigma \mathrm{X}^{2}$ & 189256.25 & 134618.75 & 323875 \\
\hline & M & 135.55 & 111.65 & 247.19 \\
\hline
\end{tabular}

Berdasarkan tabel di atas, maka dilakukan perhitungan analisis varians (Anava) faktorial sight singing dengan media pembelajaran. Ringkasan hasil perhitungannya dapat dilihat pada tabel 4 sebagai berikut:

Tabel 3. Ringkasan Perhitungan Anava Faktorial Sight Singing Dengan Media Pembelajaran

\begin{tabular}{|l|l|l|l|l|l|}
\hline $\begin{array}{l}\text { Sumber } \\
\text { Variasi }\end{array}$ & JK & db & RJK & $F_{h}$ & $F_{\text {tab }}$ \\
\hline A & 1773,70 & 1 & 1773,70 & $\left.\mathbf{2 0 , 0 4 8}^{*}\right)$ & 3,26 \\
B & 2455,95 & 1 & 2455,95 & $\mathbf{2 7 , 7 6 0 * )}$ & 3,26 \\
Inter AB & 2062,64 & 1 & 2062,64 & $\mathbf{2 3 , 3 1 4 * )}$ & 3,26 \\
dalam & 3184,95 & 36 & 84,47 & -- & -- \\
\hline Total & 17389,74 & 39 & -- & -- & \\
\hline
\end{tabular}

Hasil perhitungan nilai $\mathrm{F}_{\mathrm{A}}$ adalah $20,048^{*}$ (signifikan). Artinya terdapat perbedaan yang signifikan hasil belajar musik ansambel siswa antara yang diajar dengan media pembelajaran Power Point dan video. Media pembelajaran berpengaruh terhadap peningkatan hasil belajar musik ansambel siswa. Hasil perhitungan nilai $F_{B}$ adalah 27,760* (signifikan). Artinya terdapat perbedaan yang signifikan hasil belajar musik ansambel siswa antara siswa yang memiliki sight singing tinggi dan rendah. Kemampuan sight singing berpengaruh terhadap peningkatan hasil belajar musik ansambel. Hasil perhitungan nilai $\mathrm{F}_{\mathrm{AB}}$ adalah $23,314^{*}$ (signifikan). Artinya terdapat interaksi antara media pembelajaran dengan kemampuan sight singing terhadap hasil belajar musik ansambel siswa.

Rangkuman hasil perhitungan Uji Scheffe dapat dilihat pada Tabel 5 berikut.

Tabel 5. Ringkasan Hasil Pengujian Dengan Menggunakan Uji Scheffe

\begin{tabular}{|l|l|c|c|}
\hline No & \multicolumn{1}{|c|}{ Uraian } & F $_{\text {hitung }}$ & F tabel $^{|c|}$ \\
\hline 1 & $\begin{array}{l}\text { Perbedaan hasil belajar musik ansambel siswa yang memiliki kemampuan sight singing tinggi } \\
\text { pada kelas media pembelajaran power point }\left(\mathrm{A}_{1} \mathrm{~B}_{1}\right) \text { dengan hasil belajar musik ansambel } \\
\text { siswa yang memiliki kemampuan sight singing rendah pada kelas media pembelajaran power } \\
\text { point }\left(\mathrm{A}_{1} \mathrm{~B}_{2}\right)\end{array}$ & 0,700 & 2,61 \\
\hline 2 & $\begin{array}{l}\text { Perbedaan hasil belajar musik ansambel siswa yang memiliki kemampuan sight singing tinggi } \\
\text { pada kelas media pembelajaran power point }\left(\mathrm{A}_{1} \mathrm{~B}_{1}\right) \text { dengan hasil belajar musik ansambel } \\
\text { siswa yang memiliki kemampuan sight singing tinggi pada kelas media pembelajaran video } \\
\left(\mathrm{A}_{2} \mathrm{~B}_{1}\right)\end{array}$ & 0,239 & 2,60 \\
\hline 3 & $\begin{array}{l}\text { Perbedaan hasil belajar musik ansambel siswa yang memiliki kemampuan sight singing tinggi } \\
\text { pada kelas media pembelajaran power point }\left(\mathrm{A}_{1} \mathrm{~B}_{1}\right) \text { dengan hasil belajar musik ansambel } \\
\text { siswa yang memiliki kemampuan sight singing rendah pada kelas media pembelajaran video } \\
\left(\mathrm{A}_{2} \mathrm{~B}_{2}\right)\end{array}$ & 13,868 & 2,61 \\
\hline
\end{tabular}




\begin{tabular}{|l|l|l|l|}
\hline No & \multicolumn{1}{|c|}{ Uraian } & $\mathbf{F}_{\text {hitung }}$ & $\mathbf{F}_{\text {tabel }}$ \\
\hline 4 & $\begin{array}{l}\text { Perbedaan hasil belajar musik ansambel siswa yang memiliki kemampuan sight singing } \\
\text { rendah pada kelas media pembelajaran power point }\left(\mathrm{A}_{1} \mathrm{~B}_{2}\right) \text { dengan hasil belajar musik } \\
\text { ansambel siswa yang memiliki kemampuan sight singing tinggi pada kelas media } \\
\text { pembelajaran video }\left(\mathrm{A}_{2} \mathrm{~B}_{1}\right)\end{array}$ & 0,949 & 2,60 \\
\hline 5 & $\begin{array}{l}\text { Perbedaan hasil belajar musik ansambel siswa yang memiliki kemampuan sight singing } \\
\text { rendah pada kelas media pembelajaran power point }\left(\mathrm{A}_{1} \mathrm{~B}_{2}\right) \text { dengan hasil belajar musik } \\
\text { ansambel siswa yang memiliki kemampuan sight singing rendah pada kelas media } \\
\text { pembelajaran video }\left(\mathrm{A}_{2} \mathrm{~B}_{2}\right)\end{array}$ & 13,168 & 2,61 \\
\hline 6 & $\begin{array}{l}\text { Perbedaan hasil belajar musik ansambel siswa yang memiliki kemampuan sight singing tinggi } \\
\text { pada kelas media pembelajaran video }\left(\mathrm{A}_{2} \mathrm{~B}_{1}\right) \text { dengan hasil belajar musik ansambel siswa } \\
\text { yang memiliki kemampuan sight singing rendah pada kelas media pembelajaran video } \\
\left(\mathrm{A}_{2} \mathrm{~B}_{2}\right)\end{array}$ & 2,60 \\
\hline
\end{tabular}

Hasil pengujian hipotesis di atas, menunjukkan adanya interaksi antara strategi pembelajaran dan gaya belajar terhadap hasil belajar gambar teknik mesin.

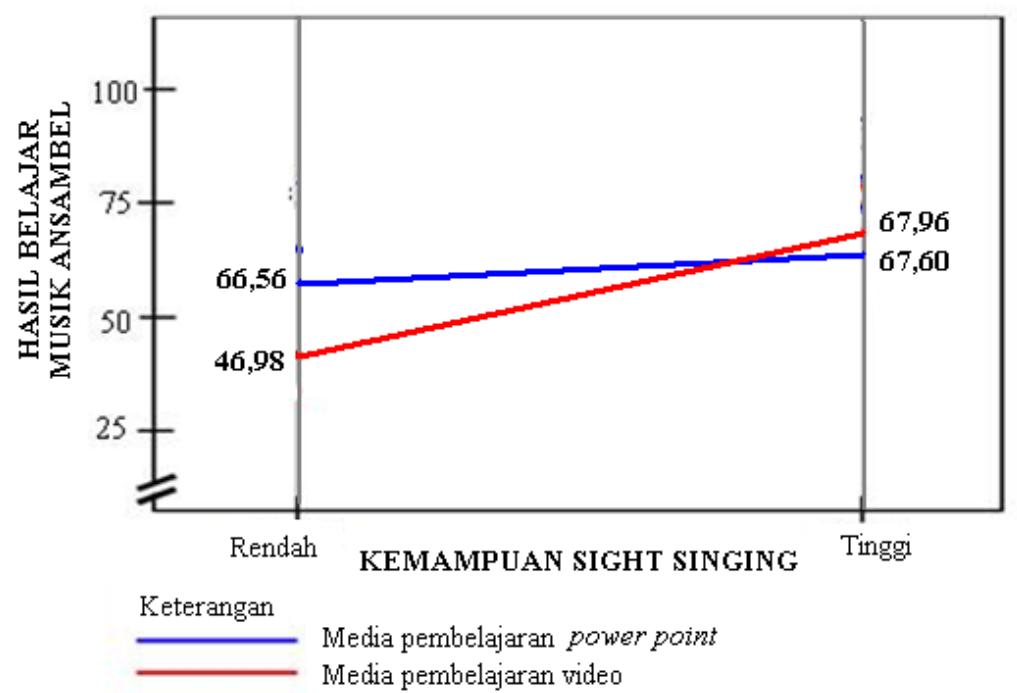

Gambar 1. Interaksi antara Media Pembelajaran dengan Kemampuan Sight Singing

\section{PEMBAHASAN}

Microsoft Power Point merupakan program aplikasi presentasi dalam komputer. Sebagai program aplikasi presentasi yang popular, Power Point paling banyak digunakan untuk kepentingan presentasi baik presentasi produk, meeting, seminar, lokakarya, dan dalam pembelajaran. Sehingga ini dapat membuat presenntasi secara professional bahkan jika perlu hasil power point dapat ditempatkan di server web untuk diakses sebagai bahan pembelajaran atau informasi lainnya. Selain mudah, power point dapat diintegrasikan dengan microsoft yang lain seperti word, excel, access, dan lain-lain.

Siswa lebih aktif dalam mengikuti pembelajaran dengan menggunakan media Microsoft Power Point karena media power point memiliki keunggulan yakni (1) mampu menampilkan objek-objek yang sebenarnya tidak ada secara fisik. (2) mampu mengembangkan materi pembelajaran terutama membaca dan mendengarkan secara mudah. (3) memiliki kemampuan dalam menggabungkan semua unsur media seperti teks, gambar, video, grafik, tabel, suara, dan animasi menjadi satu penyajian yang terintegrasi. (4) dapat mengakomodasi peserta didik sesuai dengan modalitas belajarnya terutama bagi siswa yang memiliki tipe visual, auditif, kinestetik, dan lain-lain.

Berdasarkan hasil penelitian pembelajaran dengan menggunakan media video kurang efektif untuk memudahkan siswa dalam belajar, karena dalam pembelajaran ini siswa kurang dilibatkan secara keseluruhan sehingga mempengaruhi dalam proses daya tangkap siswa terhadap materi pelajaran. Dengan demikian pengetahuan yang mereka diperoleh tidak sebanyak yang diperoleh siswa yang diajarkan dengan menggunakan media pembelajaran power point.

Keaktifan siswa dengan menggunakan media power point ternyata dapat meningkatkan 
minat dan motivasi siswa belajar, hal ini karena melalui media power point siswa lebih mudah memahami pelajaran. Pembelajaran seperti ini akan menjadikan siswa aktif dalam kegiatan belajar mengajar, sehingga mereka akan cepat memahami materi pembelajaran yang diberikan. Berdasarkan hal tersebut, dari penelitian ini jelas bahwa pembelajaran dengan menggunakan media pembelajaran power point memberi pengaruh yang lebih baik terhadap hasil belajar musik ansambel dibandingkan dengan pembelajaran menggunakan media video.

Sight singing yaitu proses membaca notasi musik dan menghasilkan suara yang diwakili dengan nyanyian tanpa acuan pada sumber mekanik ketukan. Holmes menjelaskan para ahli musik mendefenisikan sight singing sebagai kemampuan mengubah notasi musik ke dalam bunyi dalam bentuk penyajian suara. Dalam latihan sight singing mengikut sertakan keahlian yang kompleks yang dibutuhkan oleh penyanyi untuk menggabungkan irama, dinamik dan simbol artikulasi (pengucapan tanda).

Holmes dalam Sinaga (2010:17) menjelaskan lebih lanjut mengenai kemampuan sight singing berkaitan dengan kemampuan individu yaitu: (1) Analysis of eye movement berkaitan dengan kemampuan individu untuk melakukan gerakan mata dalam membaca notasi musik Holmes dalam Sinaga (2010:17) mengutip kajian yang berkaitan dengan analysis of eye movement yaitu penelitian yang dilakukan oleh Goolsby. Dalam hal ini Gollsby melakukan pengujian pengukuran terhadap analysis of eye movement dimana hasil temuannya menunjukkan terdapat hubungan analysis of eye movement dengan kemampuan sight singing. Semakin cepat dan baik gerakan mata dalam melihat notasi musik maka kemampuan sigh singing semakin baik. Untuk menguji dan mengukur kemampuan ini dilakukan dengan cara membaca notasi musik baik notasi angka maupun notasi balok, kemudian mengukur kecepatan dan ketepatannya membaca notasi musik tersebut. (2) Melodic Intervals berkaitan dengan kemampuan individu untuk membaca jarak antara dua buah nada dalam pitch secara harmonic atau melodi. Menurut Banoe (2003:196) interval adalah jarak antara nada. Jenis interval yaitu prime (jarak 1 nada), second (jarak 2 nada), terts (jarak 3 nada), kwart (jarak 4 nada), kwint (jarak 5 nada), sext (jarak 6 nada), septim (jarak 7 nada), dan oktaf (jarak 8 nada).(3) Reading rhtyhm, berkaitan dengan kemampuan individu membaca perbedaan nilai not sehingga membentuk irama yang saling berkaitan yang menghasilkan keindahan dalam melodi.

Berdasarkan penjabaran di atas maka dapat disimpulkan bahwa kemampuan sight singing adalah kemampuan individu untuk mengkonversi notasi musik ke dalam bunyi suara. Kemampuan sight singing berkaitan dengan kemampuan individu tentang interval, rhtym (irama), dinamik, tempo, dan lambang artikulasi yang terdapat dalam melodi dan untuk selanjutnya dapat menyanyikan dengan baik dan benar. Siswa yang memiliki kemampuan sight singing yang tinggi mampu membaca notasi musik atau dapat menyanyikan notasi musik dengan lancar dan dengan pitch yang tepat. Sehingga dalam pembelajaran musik Ansambel, siswa tersebut tidak menemukan kesulitan dalam membaca atau mengartikan notasi musik. Sebaliknya, siswa yang memiliki kemampuan sight singing rendah, mengalami kesulitan dalam membaca notasi musik, dan memerlukan waktu yang cukup lama untuk dapat mengerti notasi musik yang akan dimainkan dalam pembelajaran musik ansambel. Sehingga memperoleh hasil belajar yang kurang maksimal. Berdasarkan hal tersebut, dapat disimpulkan bahwa siswa yang memiliki kemampuan sight singing yang tinggi memperoleh hasil belajar musik Ansambel yang lebih tinggi, dibandingkan dengan siswa yang memiliki kemampuan sight singing yang rendah.

Penelitian ini menyimpulkan bahwa terdapat interaksi antara pembelajaran dengan menggunakan media pembelajaran dengan sight singing siswa terhadap hasil belajar musik ansambel. Tampak pada grafik pada gambar 4.7 yang terdapat pada halaman 78, bahwa penerapan pembelajaran dengan media pembelajaran Power Point dan penerapan dengan media video memberi pengaruh yang berbeda secara signifikan terhadap hasil belajar musik ansambel siswa terlepas dari sight singing siswa. Sebaliknya sight singing tinggi dan sight singing rendah siswa memberi pengaruh yang berbeda terhadap hasil belajar musik ansambel terlepas dari media pembelajaran yang digunakan, sehingga hipotesis alternatif (Ha) diterima.

Penggunaan media video yang memberikan tayangan video kepada siswa, 
menuntut siswa memberikan perhatian lebih terutama indera pendengaran dan penglihatan. Hal ini cukup menyulitkan siswa apalagi yang memiliki kemampuan sight singing rendah. Sebab fokus konsentrasi siswa terpecah pada pemahaman notasi musik dan juga fokus untuk melihat video dengan sungguh-sungguh. Berdasarkan penjabaran tersebut, maka terdapat interaksi antara media pembelajaran dengan kemampuan sight singing terhadap hasil belajar musik Ansambel pada siswa kelas VIII SMP Swasta Boddicita Medan.

\section{PENUTUP}

Berdasarkan hasil penilitian yang telah di uraikan pada bab sebelumnya, maka ditarik kesimpulan sebagai berikut :

Terdapat perbedaan hasil belajar musik ansambel antara kelompok siswa yang diajar dengan media pembelajaran power point dengan siswa yang diajar dengan media pembelajaran video. Kelompok siswa yang diajarkan dengan media pembelajaran power point memperoleh hasil belajar yang lebih tinggi dari pada kelompok siswa yang diajar dengan media video

Berdasarkan hasil penelitian pembelajaran dengan menggunakan media video kurang efektif untuk memudahkan siswa dalam belajar, karena dalam pembelajaran ini siswa kurang dilibatkan secara keseluruhan sehingga mempengaruhi dalam proses daya tangkap siswa terhadap materi pelajaran. Dengan demikian pengetahuan yang mereka diperoleh tidak sebanyak yang diperoleh siswa yang diajarkan dengan menggunakan media pembelajaran power point.

Terdapat perbedaan hasil belajar musik ansambel antara kelompok siswa yang memiliki kemampuan sight singing tinggi dengan kelompok siswa yang memiliki kemampuan sight singing rendah. Siswa yang memiliki kemampuan sight singing tinggi memperoleh hasil belajar tinggi dari pada kelompok siswa yang memiliki kemampuan sight singing rendah

Terdapat interaksi antara penerapan pembelajaran dengan media pembelajaran power point dan media pembelajaran video dengan tinggi rendahnya kemampuan sight singing siswa terhadap hasil belajar musik ansambel siswa

\section{DAFTAR PUSTAKA}

Arsyad, Azhar.2013. Media Pembelajaran. Jakarta: Rajawali Pers.
Baswedan, A. 2014. Pendidikan Indonesia Gawat Darurat. Artikel Koran. [online] tersedia: http://edukasi.kompas.com [1 desember 2014]

Banoe, Pono. 2003. Kamus Musik. Yogyakarta: Kanisius.

Constantinescu, A.I. 2007. Using Technology to Assist in Vocabulary Acquisition and Reading Comprehension. The Internet TESL Journal, Vol. XIII, No. 2, February 2007. [On-line]. Tersedia http://iteslj.org/Articles/ConstantinescuVpcabulary.html. (diakses tanggal 5 Januari 2016)

Erick, Taylor. 1989. The AB Guide To Music theory Part I. London: Royal Schools of Music.

Fraenkel, J. R, Wallen, N. E. 2008. How to Design and Evaluate Research in Education.New York: McGraw Hill

Gerlach dan Ely. 1971. Teaching \& Media: A Systematic Approach Second Edition. Boston: Allyn and Bacon.

Hamalik, Oemar. 2009. Kurikulum dan Pembelajaran. Jakarta: Bumi Aksara.

Hamdani. 2010. Strategi Belajar Mengajar. Bandung: Pustaka Setia.

Kamien, Roger. 1994. Music An Appreciation Second Brief Edition. New York: McGraw-Hill, Inc.

Mack, Dieter. 1995. Ilmu Melodi. Yogyakarta: Pusat Musik Liturgi.

Panjaitan, Keysar. 2010. Merancang Butir Soal dan Instrument untuk Penelitian. Gorontalo: Nurul Jannah.

Prier, Karl-Edmund SJ. 2011. Ilmu Bentuk Musik. Yogyakarta: Pusat Musik Liturgi

Sanjaya, W. 2008. Strategi Pembelajaran Berorentasi Standar Proses Pendidikan. Jakarta : Kencana Prenada Media Group

Sheppard, Philip. 2007. Music Makes Your Child Smarter. Jakarta: Gramedia.

Sinaga, Theodora. 2010. Penerapan strategi Pembelajaran Untuk Meningkatkan Kemampuan Sight Singing Mahasiswa Dalam Mata Kuliah Solfegio Program Studi Musik Jurusan Sendratasik FBS UNIMED. Tesis. Universitas Negeri Medan.

Sudjana, Nana. 2010. Penilaian Hasil Proses Belajar Mengajar. Bandung: Remaja Rosdakarya.

Bandung: Tarsito. 
Sugiyono. 2008. Metode Penelitian Bisnis

Pendekatan Kuantitatif, Kualitatif, dan $R \& D$. Bandung: Alfabeta.

Tambajong, Japi. 1992. Ensiklopedia Musik. Bandung: PT Cipta Adi Pustaka. 